\title{
The Influence of Picture Book on Emergent Literacy of Preschool Children
}

\author{
Eka Mei Ratnasari, Enny Zubaidah \\ Yogyakarta State University, Yogyakarta, Indonesia \\ e-mail: ekameiratnasari@gmail.com
}

\begin{abstract}
The development of children is an important thing to be considered. Mostly parents and teacher focus on developing children's cognitive abilities such as the ability to recognize numbers, symbols of numbers and numeracy, while language skills are often abandoned. Necessarily, the ability of children in emergent literacy is very important to be introduced from an early age. This study aimed to determine the ability of children to literacy skill through the use of picture book at aged 4-5 years. The research subjects consisted of two kindergartens in Yogyakarta Indonesia. The data used in this study was quasi-experiment. In the experimental group used the picture book while in the control group used conventional methods. The data collection used observation sheets. The collected research data were analyzed using t-test through the SPSS program 16 to see the differences between the experimental and control groups. The conclusion of this research was a significant difference in using picture books on emergent literacy in preschool children. The recommendation from the result of this research was provided to parents, teachers, academics, surrounding environment of the children particularly to develop children's communication skill and practitioner in the discussion that especially emphasized addressing the need to increase opportunities for emergent literacy of preschool children in good stimulation.
\end{abstract}

Keywords: preschool children, picture book, emergent literacy

\section{INTRODUCTION}

The development of language skills of children is very important so that children can easily adapt to the surrounding environment. One of the abilities that can be developed in language development is literacy skills. Early childhood education is closely linked to the development of children's literacy skills. The phenomenon that occurs is a child who continues to grow over the times have different characteristics and literacy skills as well. There are children who have high literacy skills, moderate or low between each child. Most parents and teachers focus more on the cognitive abilities of children such as the ability to recognize numbers, symbols of numbers and counting, while the literacy skill is often abandoned. Though literacy skill is very important to be introduced from an early age. Most parents think that literacy activities should be taught when the child has entered the age of 6 years while the child has entered kindergarten school. The differences about parents' thinking in literacy skills are sometimes make it difficult for children to recognize letters and words. Previous research has shown that children's literacy skills should start at an early age (Soderman, Gregory \& McCarty, 2005; Tracey \& Morrow, 2006). Children's experience from an early age when interacting with literacy will prepare children for formal learning (Rees, Garnier, Gallimore \& Goldenberg: 2000). Most children have learned about reading before children can really read (Bjorklund: 2005). Therefore, the introduction of literacy needs to be stimulated and introduced to children at an early age.

However, until now the implementation in the teaching of emergent literacy has not run maximally. 
There are several schools that teach students to read, write and count. This phenomenon is supported by the results of research conducted by Istiyani (2013: 1) about parents and educational institutions in Pekalongan district to involve children in private tutoring activities to improve reading, writing and numeracy (CALISTUNG) even this activity has been followed by the children since being in group A. In addition to this, most primary schools typically conduct school entrance tests, usually in CALISTUNG. Whereas the Ministry of Education and Culture (Kemendikbud) / government confirms the acceptance of new learners (PPDB) level elementary school should not have a test read, write, count (CALISTUNG) (Republika online news: 2017).

The usual daily activities of children related to literacy such as introducing the sound of letters, names, alphabets, pretend reading behavior, making graffiti, or writing. One of the children activities can use in literacy skills is through the use of piture book. Scull, et al. (2013: 71) explains the important thing in learning a language is to read a book and engage a child in a discussion about the text being read. DeBruin-Parecki (2009) explains that the activity of reading a picture book becomes an important thing in the development of literacy skills of preschoolers. The use of picture books can be used to introduce the child to the picture, form of writing, letters, or words contained in a picture book. In addition, the content contained in a picture book should be tailored to the age of the child so that the use of picture books runs optimally.

This study aimed to determine the literacy skills of pre-school children. Based on the description that has been presented, the researcher raised the problem related to the learning process of children to know the influence of using picture book to emergent literacy of preschool children. The recommendation from the result of this research was provided to parents and teachers particularly to develop children's communication skill and practitioner in the discussion that especially emphasized addressing the need to increase opportunities for literacy skills of preschool children in good stimulation.

\subsection{Literacy}

The ability of literacy is an important thing that became the basis in the face of the progress of the times. The increasingly modern state demands the readiness of everyone to cope with change. Therefore, from an early age, the child needs to be equipped with various skills, one of which is the ability of literacy. Chomsky stated that the child since birth has the language ability and will develop according to his age. Vygotsky states that language is the result of the process of interaction with the social environment. Both theories derived from Chomsky and Vygotsky can be concluded that the ability of literacy can be influenced by factors from the inside (genetic) and from outside (environment). Children that have a good literacy skill will be very good for their future. Rohde (2015) explains that it is important to ensure that children acquire the skills and early awareness that children need to become successful readers and authors.

Literacy comes from the Latin "literatus" which means letter, literate, or educated (Toharudin: 2011). In addition, literacy also means understanding, involving, using, analyzing and transforming text (Alwasilah: 2012). Susanto (2017) explains that the term literacy has evolved for a long time, the meaning of literacy has changed over time, this has resulted in widespread definition defined. Literacy is both dynamic and relative. Pentimonti \& Justice, (2010: 241) said that the development of literacy is a complex process and begins before the emergence of formal reading instructions. Knowledge gained into an early activity in reading and writing, this is often referred to as emergent literacy.

Literacy can be interpreted as the ability to read and write. Mustafa (2008: 2) explains that emergent literacy is an informal process of reading and writing that generally tells of stories such as reading-writing demonstrations, interactive collaboration between parents and children, based on daily needs, and with minimal but direct teaching methods (minimum direct). Literacy has a broad meaning (multi-literacy). These are computer literacy, media literacy, technological literacy, economic literacy, information literacy, and moral literacy Ane, 2015: 148. Emergents literacy are defined as concepts that support reading and writing learning when children are in the process of being literate or in literacy (Soderman, Gregory \& McCarty, 2005; Tracey \& Morrow, 2006; Astuti, 2014). Literacy is how young children learn to read and write (Carolline \& Marry: 2002: 2).

Emergent literacy consists of 2 sets of skills and processes namely inside-out and outside-in. In the inside-out domain is the knowledge of the rules 
or how to transform the writing into the form of sound and voice into written form. While the outside-in domain is an information source that comes from outside the writing that directs understanding of the meaning of writing, such as vocabulary, story schema, conceptual knowledge. Both of these processes are unified and inseparable (Papalia, D. E., Olds, S. W., \& Feldman R. D, 2001; Whitehurst \& Lonigan, 2001). Emergency literacy refers to the knowledge, skills, and attitudes that the child has in relation to reading and writing. Rohde (2015) explains that the emergence literature includes alphabetical knowledge and abilities, phonological awareness, symbolic representation, and communication. The development of emergent literacy is a precursor of the activity of reading and writing (Astuti, 2014).

Walker \& Karen (2014: 89) describes the results of a National Early Literacy Panel (2008) study of six reading skills: 1) alphabetical knowledge, 2) phonological awareness, 3) mentioning letters and numbers quickly, 4) mentioning objects and colors rapidly, 5) the activity of writing or writing names, and 6) phonological memory. It is not much different from the exposure conveyed by Walker \& Karen, Morrison (2012: 261) mentions that children need knowledge of the letters, the speed of the child mentioning the name of the letters, the phonemic understanding or the impression of the letters, and the experience of reading and being read by a person other.

The environment has an important impact on the development of children's literacy. There are many ways to improve children's literacy skills such as creating a comfortable literacy environment for children, in an environment of literacy, there are many activities that can be done. The introduction of emergent literacy should be introduced to the child through an enriching way or activity, and in accordance with the child's developmental level of ability. Snow (2008: 275) describes emergent literacy skills in preschoolers as the capacity to name letters and write them down, spelling simple words, identifying letters and signs around the child, identifying books from titles and doing book-related activities. Activities in the form of reading stories using picture books together are one way that can be used to improve the ability of children's literacy.

\subsection{Picture book}

Children have not been able to understand the learning process only in verbal form. Therefore, the media is very important in the learning process. The delivery of such learning must be balanced with the help of the media to clarify the goals to be conveyed to the child. The most child-friendly media is the book. The material contained in the book is tailored to the child's age level. The picture book is the type of book chosen by most adults to read with the children (Kotaman \& Balci, 2016: 2). The picture book gives the child an opportunity to add vocabulary so that the child can develop his or her language skills. Machado (2013: 252) explains that the teacher understands that the time of discussion through the book can help the children to build vocabulary, phonological awareness, and develop letter recognition. Lenhart, et al. (2017: 1) put forward a similar opinion, reading a book together can provide intervention in vocabulary development.

The picture book is book that can be used for children. This book can be used as a medium of language development of children. Reed et al. (2015: 367 ) describe storytelling through picture books in peer groups can stimulate reasoning for children aged 4.5 to 6 years. The picture in the picture book will be more effective for the child in understanding the story than the one containing only the text. Lukens (2003: 40) explained that images make children understand the contents in a single look, in contrast to the writing that needs to be understood little by little. Through pictures, children will be invited or guided profit link what read with illustrations in the book. Images can create an atmosphere of the soul through the background image or make children more deeply about the character by seeing the hue and look at the performance. Children can see the color of clothing, the face shape of the character, the atmosphere of the story and so forth with the help of story illustrations (Lukens, 2003: 45).

Mantei \& Kervin (2014: 76) explains that picture books are one of the most important and accessible forms of visual art as they provide opportunities for children to explore personal experiences and understand family and social values. The picture book is a book-shaped story, there are pictures as representatives of interrelated stories and also there are writings that can represent the story displayed by the picture. Through the media, images can strengthen the memory and facilitate 
understanding in understanding the contents of the story. The exposure, supported by Toha-sarumpaet (2010: 18) which explains that picture book is a book that presents the story using the picture. Picture books are a great choice for children because they are fun for children, picture books in them are colorful drawing designs that make children enjoy reading, language processing and meaningful themes into one of the greatest interests in picture books. Through the picture book as can see all the pictures at once, while the text looks a bit (Mitchell, 2003: 40). The different expositions are presented by (Bower, 2014; Biddle, 2014; Mitchell, 2003) picture books are stories in which there are words and images, picture books composed of interrelated images and texts. Both are complementary in order to describe a story.

Based on some opinions that have been described, it can be concluded that the picture book is a book-shaped story, there are images as representatives of interrelated stories and also there is writing that can represent the story displayed by the picture. The main elements of the storybook are stories and pictures. Images make the child understand the content in a single look, in contrast to the writing that needs to be understood little by little. Through pictures, children will be invited to link what is read with the illustrations in the book.

\section{METHOD}

The research method used in this research is quantitative research using a quasi-experimental approach. In quasi-experiments, researchers used experimental and control groups, but did not randomly assign participants to the two groups (Cresswell, 2016: 228). It means quasi-experiment because not all variables can be controlled. In experimental design, the primary objective is to examine the impact of a treatment or an intervention on the results of a study controlled by other factors which may also affect the outcome (Cresswell, 2016: 208).

The instrument used in measuring emergent literacy skill is usually uses "Get Ready to Read" measuring instrument. Whitehurts \& Lonigan (2001) explained that in evaluating emergent literacy skills use a "Get Ready to Read" measuring instrument. The measuring instrument has a reliability value of 0.8. Similar to the previous opinion, Molfese et al. (2006) explained that his research used a "Get Ready to Read" measurement tool to measure emergent literacy skills. Therefore, the researchers adopted a "Get Ready to Read" measurement tool to measure the ability of emergent literacy of preschoolers. The grid development of emergent literacy can be seen in table 1 as follows

Table 1 Grid Development of Emergent Literacy

\begin{tabular}{lll}
\hline Domain & \multicolumn{1}{c}{ Unit } & \multicolumn{1}{c}{ Skill } \\
\hline Inside- & Phonological & Syllable / sound matching \\
& awareness of sound & \\
& & $\begin{array}{l}\text { Identification of rhythmic } \\
\text { sounds / syllables }\end{array}$ \\
& Addition / substitution of \\
& sounds / syllables \\
& Sound / syllable deletion \\
& Writing & Knowledge of letters \\
& & Relationship of letters \\
& & with sound \\
& Emergency writing \\
& & Writing concept \\
Outside- & & Vocabulary \\
in & &
\end{tabular}

This research was conducted to determine the effect of the use of illustrated picture book to literacy skills of children 4 to 5 years of age. The experimental class is given learning by using picture book, while the control class is using conventional learning. This research was done in ABA Pringwulung and ABA Cempaka Yogyakarta. The
Form

Instructions to designate an image whose front sound corresponds to the targeted word

Instructions for pointing a picture with a back sound corresponding to the targeted word

Instructions to designate images in the form of a new syllable

Instructions for selecting images whose front syllables are omitted

Instructions for selecting the requested letter

Instructions for selecting letters that have a certain sound

Instructions for identifying good writing Instructions for identifying the characteristics of a book Expressive and receptive languages that are mastered through pictures and children are asked to mention their names

subjects in this study using purposive sampling technique, purposive sampling technique is a sample determination technique with certain considerations. The subjects of this research were 4-5 years old children, 40 in total. The subjects were divided into 20 children in the experiment group in $\mathrm{ABA}$ Pringwulung and 20 children in the control group in 
ABA Cempaka. The data of this research consisted of pre-test data and post-test of children's literacy skill. The technique of data collection used in this research was through observation while data analysis was by t-test which uses SPSS 16 program.

\section{RESULT AND DISCUSSION}

Awareness about children's literacy becomes very important for the development of children's abilities. The importance of stimulating children's literacy skills is fundamental in developing children's literacy skills. The developing emergency literacy is essential for early childhood. One of the efforts that can be done is with the use of picture books. some studies say that reading stories to children can improve the ability of children's literacy. Literacy activities support the achievement of children's literacy skills (Lynch, 2008).

The result of the research on the literacy skills of children through picture book by using t-test analysis technique (independent sample t-test) is calculated by using SPSS 16.0 for windows program. Criteria for decision making used in this study is if the significant value obtained is smaller than 0.05 then $\mathrm{H}_{0}$ rejected, this shows there is a significant difference between the experimental group and the control group. The result of the t-test can be seen in table 2 as follows.

Table 2. Independent Test Results Sample Pretest and Posttest Literacy Ability of Experiment and Control Group

\section{Group Statistics}

\begin{tabular}{|c|c|c|c|c|c|}
\hline & Kelas & $\mathrm{N}$ & Mean & Std. Deviation & Std. Error Mean \\
\hline \multirow[t]{2}{*}{ Literasi } & A1 & 20 & 80.50 & 7.237 & 1.618 \\
\hline & $\mathrm{A} 2$ & 20 & 70.75 & 7.482 & 1.673 \\
\hline
\end{tabular}

\section{Independent Samples Test}

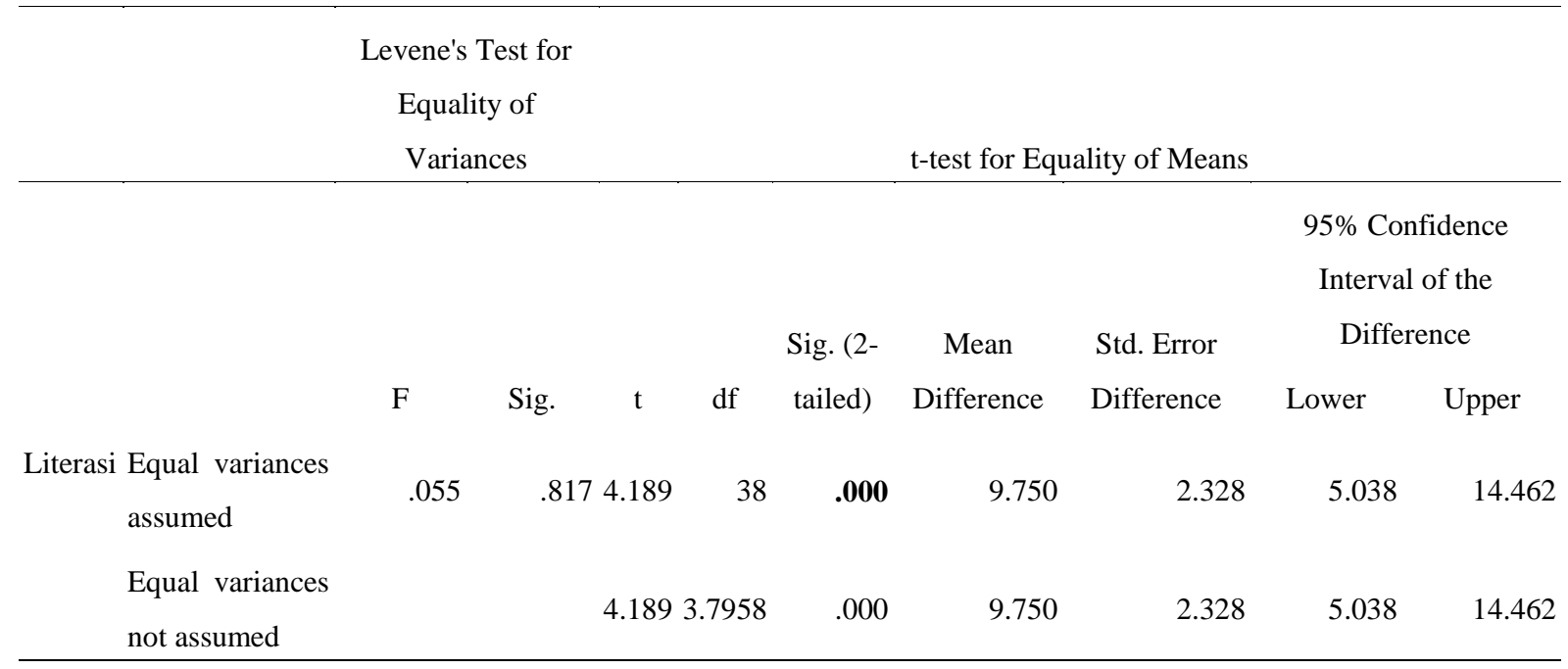

Based on the summary of the t-test of independent sample posttest on literacy skills of children showed different literacy skill in experimental group and control group. The result of the posttest data in literacy skills by using error level 0,05 hence can be concluded that $\mathrm{H}_{0}$ is rejected because obtained by the result of the value of $\mathrm{Sig}<$ a $(0.000<0.05)$. Based on the result of the calculation, posttest result of literacy skill showed that there is the difference between the experiment and control group.

During this study, Class A was given treatment in the form of use of picture book, while in class B using the conventional method. The results showed that there is a significant influence of the use of picture book to literacy skills of children. These 
results indicate that the children who are given learning with the picture book have a higher literacy skill than before the learning. The improvement of literacy skills in children occurs because learning by using picture book is one of the strategies that can be used to develop the principle of play while learning and make the child as the center in learning process. This means that the learning process is obtained through activities or activities that are done alone or in groups.

The results of this study are supported by the other research, Cunningham (2008: 33), explained that the quality of the child's environment during preschool plays an important role in developing the attitude of reading and writing, and questions about the potential impact of quality on the pattern of development during early childhood. This statement proves that through the provision and facilities provided to children in a literacy-rich environment can help the child develop his reading skills. Other research from Coyne, M., Simmons, D., Kame'enui, E., \& Stoolmiller, M (2004: 12 (3), 145-162) describes his findings of a picture book intervention program with explicit vocabulary instruction investigated in this experimental study. Interventions focused on 34 kindergarten students, the results showed students in the treatment group with low vocabulary acceptance, had a greater advantage in vocabulary mastery than the control group. These findings indicate reading a picture book along with vocabulary interaction can help reduce or prevent the widening of the vocabulary gap between kindergarten students.

In addition to the results of the research already mentioned, there are presentations given by Afnida, M., Fakhriah, \& Fitriani, D. (2016: 53) on the use of picture books in the development of the language of children in kindergarten A in Banda Aceh. This study explains that the use of picture book used by teachers can improve the language skills of children. Interactions that occur between teachers and students can be well established through the use of picture books. So the level of language ability of children increases. Reed et al. (2015) who says that storytelling through picture books in peer groups can stimulate reasoning for children aged 4.5 to 6 years. The picture in the picture book will be more effective for the child in understanding the story than the one containing only the text. Further exposure comes from Raikes et al. (2006); Stephenson et al. (2008); Aram, Most \& Mayafit (2006) explain that the stimulation of the child in the form of reading a picture book correlates with phonological awareness, general knowledge, and receptive language.

\section{CONCLUSION}

The results showed that proper stimulation activities can improve the literacy skills of preschool children. This is shown based on the result of Sig $<a(0.000<0.05)$. The conclusion of the results of this study proves that by providing appropriate stimulus in this form of the use of picture book, children can improve literacy skills. Recommendation from this research, it is expected that parents, teachers, and the environment around children support activities in stimulating the development of literacy skills and guide in every activity of literacy done by the child

\section{REFERENCES}

[1] Afnida, M., Fakhriah., \& Fitriani, D. (2016). Penggunaan buku cerita bergambar dalam pengembangan bahasa anak pada TK A di Banda Aceh. Jurnal ilmiah mahasiswa pendidikan anak usia dini, 1 (1): 52-59. Retrieved from http://www.jim.unsyiah.ac.id

[2] Alwasilah, A.C. (2012). Pokoknya rekayasa literasi. Bandung: PT. Kiblat Buku Utama.

[3] Ane, P. (2015). Membangun kualitas bangsa dengan budaya literasi. Prosiding Seminar Nasional Bulan Bahasa UNIB 2015.

[4] Aram, D., Most, T., Mayafit, H. (2006). Contribution of mother-child stor-book telling and joint writing to literacy development in kindergarteners with hearing loss. Language, Speech, and Hearing Services in School, 37(1), 209-223.

[5] Astuti, P.T. (2014). Perbedaan literasi emergen anak taman kanak-kanak didaerah perkotaan dan pingiran. Jurnal Psikologi Undip. Vol. 13, Iss 2; p. 107-119.

[6] Biddle, K.A.G., Nevarez, A.G., Henderson, W.J.R., \& Vallero-Kerrick, A. (2014). Early childhood education becoming a professional. Printed in USA: SAGE Publications, Inc.

[7] Bjorklund, D. F. (2005). Children's thinking Cognitive development and individual differences. Belmont, CA: Thomson Wadsworth Learning.

[8] Bower, V. (2014). Developing early literacy 0 to 8 from theory to practice. London: Sage publication L.td.

[9] Brooks, P.J. \& Kempe, V. (2012). Language development. Great Britain: TJ International, Padstow, Cornwall.

[10] Carolline \& Mary. (2000). Literacy learning in early years. Australia: NLA. 
[11] Coyne, M., Simmons, D. C., Kame'enui, E., \& Stoolmiller, M. (2004). Teaching vocabulary during shared storybook readings: An examination of differential effects. Exceptionality: A Special Education Journal, 12(3), 145-162. http://dx.doi.org/10.1207/s15327035ex1203_3

[12] Cunningham, D. (2008). Literacy environtment quality in preschool and children's attitudes toward reading and writing. Literacy Teaching and Learning. Vol.12. No. 2 p19-36. Spring.

[13] DeBruin-Parecki, A. (2009). Establishing a familiy literacy program with a focus on interactive reading: The role of research and accountability. Early Childhood Education Journal, 36(5), 385-392.

[14] Lenhart, J., Lenhard, W., Vaahtoranta, E., \& Suggate, S. (2017). Incidental vocabulary acquisition from listening to stories : a comparison between read-aloud and free storytelling approaches. Educational Psychology, 1-21. https://doi.org/10.1080/01443410.2017.1363377

[15] Lukens, J. R. (2003). A critical handbook of children's literature. United States of America: Pearson Education, Inc.

[16] Lynch, J et al. (2006). Parent's beliefs about young, children's literacy development and parent's literacy behaviors. Reading Psychology, 27, 1-20. doi. $10.1080 / 02720271500468708$.

[17] Machado, J. M. (2013).Early childhood experiences in language arts early literacy (10th ed). Wadsworth. Cengage Learning.

[18] Mantei, J. \& Kervin, L. (2014). Interpreting the images in a picture book: students make connections to themselves, their lives and experience. English Teaching: Practice and Critique. Vol. 13, No. 2 pp. 76-92. http://education.waikato.ac.nz/research/files/etp c/files/2014v13n2art5.pdf

[19] Mitchell, D. (2003). Children's literature an invitation to the world. Boston: Peaarson Education, Inc.

[20] Molfese, V. J., et al. (2006). Letter knowledge, phonological processing, and print knowledge: skill development in nonreading preschool children. Journal Learning Disability, 34 (4), 296-305.

[21] Morrison, S. (2012). Dasar-dasar pendidikan anak usia dini edisi kelima. (Terjemahan Suci Romadhona \& Apri Widiastuti). Jakarta: PT. Indeks. (Edisi asli diterbitkan tahun 2008 oleh Pearson Education, Inc. New Jersey).

[22] Musfiroh, T. (2017). Psikolinguistik edukasional psikolinguistik untuk pendidikan bahasa. Yogyakarta: Tiara Wacana.

[23] Mustafa. (2008). Dari literasi dini ke literasi teknologi. Jakarta: Yayasan CREST.

[24] Istiyani, D. (2013). Model pembelajaran membaca menulis menghitung (CALISTUNG) pada anak usia dini di kabupaten Pekalongan. Jurnal penelitian Vol. 10, No. 1Mei2013. Hlm. 1-18. Retrieved from https://doi.org/10.28918/jupe.v10i1.351
[25] Papalia, D. E., Olds, S. W., \& Feldman R. D. (2001). Human development. Boston: McGraw Hill.

[26] Pentimonti, J.M. \& Justice, L.M. (2010). Teachers' use of scaffolding strategies during read alouds in the preschool classroom. Early Childhood Educ J. 37: 241-248. doi. 10.1007/s1064-009-00348-6. Springer.

[27] Raikes, H., et al. (2006). Mother child book reading in low income families: Correlates and outcomes during the first three years of life. Child Development, 77 (4), 924-953.

[28] Reed, H. C., Hurks, P. P. M., Kirschner, P. A., \& Jolles, J. (2015). Preschoolers' causal reasoning during shared picture book storytelling : A cross-case comparison descriptive study. Journal of Research in Childhood Education, 29: 367-389, http://www.doi.org/10.1080/02568543.2015.10 42126

[29] Reese, L., Garnier, H., Gallimore, \& Goldenberg. (2000). Longitudinal analysis of the antecedents of emergent Spanish literacy and middle-school English reading achiecment of Spanish-speaking students. American Educational Research Journal, 37(3),633-662.

[30] Republika online news. (2017). Siswa Masuk SD tak Boleh Lalui Tes Calistung. Retrieved from https://www.republika.co.id/berita/nasional/umu $\mathrm{m} / 17 / 07 / 04 /$ osk0p6-siswa-masuk-sd-tak-bolehlalui-tes-calistung (acsessed 1 Agustus 2018)

[31] Rohde, L. (2015). The comprehensive emergent literacy model: Early literacy in context. SAGE Open. Pg 1-11,

[32] Scull, J., Louise, P., \& Raban, B. (2013). Young learners: Teachers' questions and prompt as oppurtunities for children's language development. University of Melbourne, Deakin University, and University of Melbourne. Research in early childhood, vol 7 No.1, 69-91. Retrieved from http://research.monash.edu/en/publications/youn g-learners-teachers-questions-and-prompts-asopportunities-fo

[33] Seefeldt, C., \& Wasik, B.A. (2008). Pendidikan anak usia dini, menyiapkan anak usia tiga, empat dan lima tahun masuk sekolah (Terjemahan Pius Nasar). Jakarta: PT Indeks. (Edisi asli diterbitkan tahun 2006)

[34] Smith, N. B., \& Robinson, H.A. (1980). Reading and media for learning 10 th edition. USA. Person.

[35] Snow, C.S. (2008). What counts as literacy in early childhood? Hand book of early childhood development. 274-316. Singapore: C.O.S Printers.

[36] Soderman, A.K., Gregory, K. M., \& McCarty, L.T. (2005). Scaffolding emergent literacy: a child-centered approach for preschool through grade 5. Boston: Pearson education, Inc.

[37] Stephenson, K., et al. (2008). Effects of home literacy, parent's beliefs and children's taskfocused behavior on emergent literacy and word reading skills. Scientific Studies of Reading, 12 (1), 24-50. doi: 10.1080/10888430701746864 
[38] Susanto, A. (2017). Bimbingan dan konseling di taman kanak-kanak. Jakarta: Kencana.

[39] Susanto. A. (2011). Perkembangan anak usia dini: pengantar dalam berbagai aspeknya. Jakarta: Kencana.

[40] Toharudin, dkk. (2011). Membangun literasi sains peserta didik. Bandung: Humaniora.

[41] Toha-sarumpaet, R. K. (2010). Pedoman penelitian sastra anak: edisi revisi. Jakarta: Buku Obor.
[42] Tracey, D. H \& Morrow, L. M. (2006). Lenses on reading: an introduction to theories and models. New York: The Guilford Press.

[43] Walker, K.E. (2014). Preschool teachers' constructions of early reading. Texas Journal of Literacy Education, 3 (2).

[44] Whitehurst, G. J. (2001). The NCLD geet ready to read! Screening tool technical report. Retrieved from http://www.getreadytoread.org/image/GRTR\%S creenTech.pdf. 